\title{
Digestive System Infection
}

National Cancer Institute

\section{Source}

National Cancer Institute. Digestive System Infection. NCI Thesaurus. Code C35503.

A viral, bacterial, fungal, or parasitic infectious process that affects the digestive system. 